\title{
Weed Control Efficacy and Citrus Response to Flazasulfuron Applied Alone or in Combination with Other Herbicides
}

\author{
Megh Singh ${ }^{1}$, Analiza H. M. Ramirez ${ }^{*}$, Amit J. Jhala ${ }^{1}$, Mayank Malik ${ }^{2}$ \\ ${ }^{1}$ Citrus Research and Education Center, Horticultural Sciences Department, Institute of Food and Agricultural Sciences (IFAS), Uni- \\ versity of Florida, Lake Alfred, USA; ${ }^{2}$ Monsanto Corp., Lincoln, USA. \\ Email: ${ }^{*}$ ahmramirez@ufl.edu
}

Received December $20^{\text {th }}, 2011$; revised January $19^{\text {th }}, 2012$; accepted February $10^{\text {th }}, 2012$

\begin{abstract}
Field experiments were conducted to evaluate the phytotoxicity of flazasulfuron on citrus species and efficacy on weeds when applied alone or in combination with other herbicides. Grapefruit was the most sensitive and tangerine was the least sensitive to flazasulfuron. Injury to grapefruit was $70 \%$ with the application of flazasulfuron at $0.20 \mathrm{~kg}^{2}$.i. ha ${ }^{-1}$ at $60 \mathrm{DAT}$ and was reduced $(5 \%)$ when flazasulfuron at $0.05 \mathrm{~kg}^{\mathrm{a} . i \mathrm{i}} \mathrm{ha}^{-1}$ was tank mixed with glyphosate at $0.84 \mathrm{~kg}$ a.i. $\mathrm{ha}^{-1}$. Flazasulfuron alone at all rates did not control grass weeds and common ragweed. Florida/Brazil pusley was moderately controlled with high rates of flazasulfuron from 30 to 45 DAT; however, control did not exceed $75 \%$. There was good control of Spanishneedles (78\% - 85\%) and horseweed (73\% - 81\%) with flazasulfuron at all rates at 30 DAT but control declined later in the season. Tank mix of flazasulfuron with glyphosate improved flazasulfuron efficacy on grass and broadleaf weeds. Flazasulfuron at $0.07 \mathrm{~kg}$ a.i. ha $^{-1}$ plus glyphosate at $1.70 \mathrm{~kg}$ a.i. ha ${ }^{-1}$ was more effective in controlling grass weeds $(83 \%)$ at 60 DAT and provided the highest control (79\%) of Florida/Brazil pusley at 45 DAT. There was excellent control (75\% to 94\%) of Spanishneedles and adequate control of eastern black nightshade and common ragweed with flazasulfuron tank mixed with glyphosate or diuron. This study showed that flazasulfuron alone does not adequately control grasses and some broadleaf weeds in citrus and tank mixing it with glyphosate or diuron improved flazasulfuron's efficacy. However, injury to grapefruit was observed at rates which effectively controlled weeds. Further studies are needed to determine the most suitable flazasulfuron rate that could be used to manage weeds in grapefruit.
\end{abstract}

Keywords: Chemical Weed Control; Crop Safety; Diuron; Glyphosate

\section{Introduction}

Florida is the number one producer of citrus in the U.S., contributing about $65 \%$ of the total production. Florida production for 2009-2010 was valued at $\$ 1.055$ billion from a total of 224,216 ha [1]. The total economic impact of the citrus industry based on the 2003-2004 crop year estimates was calculated to be more than $\$ 9$ billion with an employment impact of more than 76,000 jobs [2]. As for most crops, Florida citrus production is faced with various pest problems including weeds that lower yield.

Yield reduction due to weed competition translates to an estimated $23 \%-33 \%$ loss to growers [3]. Weed competition is generally more severe during the establishment phase. Young citrus trees produce little to no shade and are provided with irrigation and fertilizer for better growth, which favors weed growth [3]. Weeds not only

\footnotetext{
${ }^{*}$ Corresponding author.
}

compete for nutrients and water but may also serve as alternate hosts for insects and diseases, further reducing citrus yields; reduce soil temperatures during freezing events; and hinder grove operations such as harvesting [4].

Weed management in citrus groves is dependent on herbicides. Although other methods such as cultural, mechanical and biological control are available, they are not as cost effective as using herbicides. Current weed management options in citrus include glyphosate, a popular herbicide of choice among growers [4]. Glyphosate is either applied alone or in combination with pre- and post-emergence herbicides to adequately control a much broader spectrum of weeds in citrus. Its efficacy on many weed species and relatively low cost has made glyphosate an important component in many weed management programs [5]. However, reduced control of weeds due to the development of herbicide resistance, and a shift to more difficult-to-control weed species has 
been observed in perennial cropping systems that rely heavily on the use of one or a limited number of herbicide chemistries. Currently, several glyphosate resistant weeds have been documented in orchards, coffee (Coffea arabica L.) plantations, and vineyards in the USA, Brazil, Chile, Colombia, France, Italy, Malaysia, Spain, and South Africa [6]. In Florida, a survey of major citrus producing counties had indicated that Brazil pusley (Richardia brasiliensis (Moq.)), a weed which is not controlled with effective doses of glyphosate, was the predominant weed in citrus groves previously dominated by Florida pusley (Richardia scabra L.) [5,7]. Hence, there is a need for alternative herbicide options to better manage weeds in citrus groves not only to minimize yield losses but also to prevent, if not delay, the development of herbicide resistance and shifts in weed populations.

Flazasulfuron is a new sulfonylurea herbicide which inhibits the acetolactase synthase enzyme in susceptible plants. It is known to control a wide range of annual and perennial weeds when applied pre- and early postemergence [8]. It has been registered for use on warm season turf, grapes (Vitis vinifera L.), sugarcane (Saccharum officinale L.), and non-cropped areas in various countries in Asia, Europe, and South America [9]. In the U.S., flazasulfuron is registered under the trade name of Katana ${ }^{\circledR}$ and its use is limited to weed management in turf and for application to nonresidential areas [8]. Various research studies on turf have indicated excellent control of grass and broadleaf weed species with flazasulfuron at various rates [10-15]. Previous work that explored flazasulfuron tank mixed with other herbicides showed promising results. Wells et al. [16] indicated that Virginia buttonweed (Dioda virginiana L.) was controlled effectively by application of flazasulfuron tank mixed with a commercial product containing 2,4-D, MCPP, and dicamba. In another study, greater chamberbitter (Phyllanthus urinaria L.) control was achieved with the application of flazasulfuron at $0.05 \mathrm{~kg}$ a.i. $\mathrm{ha}^{-1}$ tank mixed with a product containing 2,4-D, dicamba, MCPP, and carfentrazone in "Tifway 419" bermudagrass [17].

There have been no studies to evaluate efficacy of flazasulfuron on weeds in citrus. As such, the current efforts are being done to determine the potential of flazasulfuron for weed management in citrus groves. The objectives of this study were to 1) evaluate the phytotoxicity of flazasulfuron on citrus and 2) to evaluate the efficacy of flazasulfuron applied singly or in combination with other herbicides on weeds of citrus in Florida.

\section{Materials and Methods}

Field experiments were conducted in 2009 in commercial citrus groves at Dundee, Haines City, and Frostproof, FL where citrus species tangerine (Citrus reticulata Blanco), sweet orange (Citrus sinensis (L.) Osbeck), and grapefruit (Citrus paradisi Macfad.) were grown, respectively. Grapefruit trees were three years old, while tangerine and sweet orange were two years old at the time of treatment application. Soil in these sites was Florida Candler sand. At each site, two studies were established. The first study consisted of application of flazasulfuron at $0.05,0.10$, and $0.20 \mathrm{~kg}$ a.i. $\mathrm{ha}^{-1}$. The second study consisted of flazasulfuron applied alone at $0.05 \mathrm{~kg}$ a.i. $\mathrm{ha}^{-1}$; flazasulfuron at $0.05 \mathrm{~kg}$ a.i. ha ${ }^{-1}$ plus glyphosate at $0.84 \mathrm{~kg}$ a.i. ha ${ }^{-1}$; flazasulfuron at $0.07 \mathrm{~kg}$ a.i. $\mathrm{ha}^{-1}$ plus glyphosate at 1.70 $\mathrm{kg}$ a.i. $\mathrm{ha}^{-1}$; flazasulfuron at $0.05 \mathrm{~kg}$ a.i. $\mathrm{ha}^{-1}$ plus diuron at $2.70 \mathrm{~kg}$ a.i. $\mathrm{ha}^{-1}$; and norflurazon at $2.70 \mathrm{~kg}$ a.i. $\mathrm{ha}^{-1}$ plus diuron at $2.70 \mathrm{~kg} \cdot \mathrm{ha}^{-1}$. A non-treated check was included for comparison. Non-ionic surfactant Induce at the rate of $0.25 \%(\mathrm{v} / \mathrm{v})$ was added to all treatments containing flazasulfuron. Treatments were arranged in a randomized complete block with four replications. Each plot measured 3-m-wide by 18-m-long and included five citrus trees. Herbicide treatments were applied with a tractor-mounted sprayer equipped with an off-set center flat fan nozzle and calibrated to deliver $187 \mathrm{~L} \cdot \mathrm{ha}^{-1}$ at 276 $\mathrm{kPa}$. Treatments were applied on April 27, April 28, and May 1, 2009 at Dundee, Haines City, and Frostproof, respectively.

Phytotoxicity on the citrus crops and percent weed control were visually evaluated based on a $0 \%-100 \%$ rating scale where 0 is no injury to citrus plants or no weed control and 100 is complete death of citrus plants or complete control of weeds. Assessment of the efficacy of various herbicide treatments on individual weed species and phytotoxicity to citrus varieties were made biweekly starting from 15 days after treatment (DAT) up to 75 DAT.

\section{Statistical Analysis}

Data on percent phytotoxicity and weed control were tested for homogeneity of variances using the Levine's test in SAS. Data from the non-treated control were not included in the analysis to improve variance homogeneity. Data transformation (arcsine square root) did not improve the variance homogeneity; hence non-transformed data were used for analysis and presentation. Data were subjected to ANOVA using the MIXED procedure in SAS, with herbicide treatments as fixed effect, while site and all other interactions were considered random effects. Means were separated using LSMEANS at the $5 \%$ level of significance.

\section{Results and Discussion}

\subsection{Citrus Response}

Application of flazasulfuron at all rates injured citrus. 
Injury was observed starting at $45 \mathrm{DAT}$ and varied by citrus species and rates (Table 1). Observed injury to citrus was characterized by chlorosis on the younger leaves followed by necrosis and, in severe cases, death of the plant. Among the citrus species, grapefruit was the most sensitive to flazasulfuron application followed by sweet orange, and the least was tangerine. Initial injury was observed at $45 \mathrm{DAT}$ and progressed by $60 \mathrm{DAT}$. At 45 DAT, grapefruit injury was $3 \%$ when flazasulfuron was applied at $0.05 \mathrm{~kg} \cdot \mathrm{ha}^{-1}$ and increased to $13 \%$ and $15 \%$ at the 0.10 and $0.20 \mathrm{~kg} \cdot \mathrm{ha}^{-1}$, respectively. No injury was observed on sweet orange and tangerine except when flazasulfuron was applied at $0.20 \mathrm{~kg} \cdot \mathrm{ha}^{-1}$ in sweet orange.

Injury at 60 DAT was $<5 \%$ when flazasulfuron was applied at $0.05 \mathrm{~kg} \cdot \mathrm{ha}^{-1}$ regardless of citrus species. However, injury was more pronounced when flazasulfuron was applied at 0.1 and $0.2 \mathrm{~kg} \cdot \mathrm{ha}^{-1}$ than at $0.05 \mathrm{~kg} \cdot \mathrm{ha}^{-1}$. Flazasulfuron application to grapefruit at 0.10 and 0.2 $\mathrm{kg} \cdot \mathrm{ha}^{-1}$ caused $42 \%$ and $70 \%$ injury, respectively; but injury was less in sweet orange $(8 \%$ and $21 \%)$ and tangerine $(6 \%$ and $20 \%)$.

Application of flazasulfuron tank mixed with low rate of glyphosate reduced its phytotoxicity to citrus compared to flazasulfuron alone (Table 2). At 45 DAT, grapefruit injury was lower when flazasulfuron at $0.05 \mathrm{~kg}$ a.i. $\mathrm{ha}^{-1}$ was tank mixed with glyphosate at $0.84 \mathrm{~kg}$ a.i. $\mathrm{ha}^{-1}$. Injury to grapefruit was $9 \%$ to $11 \%$ when flazasulfuron was applied at $0.05 \mathrm{~kg}$ a.i. $\mathrm{ha}^{-1}$ or when tank mixed with either glyphosate $\left(1.70 \mathrm{~kg}\right.$ a.i. ha $\left.{ }^{-1}\right)$ or with diuron. The same response was observed at 60 DAT (Table 2). No injury was observed on sweet orange and tangerine at 45 and 60 DAT from any herbicide treatments.

Varied crop tolerance to flazasulfuron has been reported in many crop species and settings. Turf species response to flazasulfuron varied by species. Among the turf grass species, seashore paspalum (Paspalum vaginatum Sw.), zoysia (Zoysia japonica), and bermudagrass (Cynodon dactylon L.) showed moderate to good tolerance, while common centipedegrass and Raleigh St. Augustinegrass were not tolerant to flazasulfuron $[18,19]$. Furthermore, tolerance of bermudagrass to flazasulfuron varied by variety, rates, and application timings. For example, moderate phytotoxicity $(\leq 20 \%)$ was observed when flazasulfuron was applied to bermudagrass varieties such as Sahara, Tifway 419, and Tifsport [18]. Similarly, injury of $<20 \%$ was observed with postemergence application of flazasulfuron at rates ranging from 0.008 to $0.105 \mathrm{~kg}$ a.i. ha ${ }^{-1}$, while preemergence application at $0.034 \mathrm{~kg}$ a.i. $\mathrm{ha}^{-1}$ resulted to $90 \%$ injury to seeded bermudagrass cv. Riviera and Yukon [11]. Furthermore, Willis et al. [20] reported that flazasulfuron injured bermudagrass the most among the sulfonylurea herbicides tested on seeded bermudagrass. Flazasulfuron also significantly reduced turf cover at six and nine weeks after seeding. Other researchers, however, reported considerable

Table 1. Citrus response to varying rates of flazasulfuron at 45 and 60 days after treatment (DAT).

\begin{tabular}{|c|c|c|c|c|c|c|}
\hline \multirow{3}{*}{$\begin{array}{c}\text { Rates (kg a.i. } \\
\text { ha }^{-1} \text { ) }\end{array}$} & \multicolumn{6}{|c|}{ Injury $(\%)^{\dagger}$} \\
\hline & \multicolumn{3}{|c|}{45 DAT } & \multicolumn{3}{|c|}{60 DAT } \\
\hline & Grapefruit & Orange & Tangerine & Grapefruit & Orange & Tangerine \\
\hline 0.05 & $3 \mathrm{c}^{\ddagger}$ & $0 \mathrm{c}$ & $0 \mathrm{c}$ & $1 \mathrm{ef}$ & $1 \mathrm{f}$ & 4 def \\
\hline 0.10 & $13 \mathrm{ab}$ & $3 c$ & $0 \mathrm{c}$ & $42 \mathrm{~b}$ & $8 \mathrm{~d}$ & $6 \mathrm{de}$ \\
\hline 0.20 & $15 \mathrm{a}$ & $10 \mathrm{~b}$ & $0 \mathrm{c}$ & $70 \mathrm{a}$ & $21 \mathrm{c}$ & $20 \mathrm{c}$ \\
\hline
\end{tabular}

${ }^{\dagger}$ Visual injury was based on a $0 \%-100 \%$ rating scale where 0 is no injury and 100 is complete death of plants; ${ }^{\dagger}$ Means followed by the same letter within the rating period are not significantly different at $\alpha=5 \%$.

Table 2. Citrus response to different herbicide treatments at 45 and 60 days after treatment (DAT).

\begin{tabular}{|c|c|c|c|c|c|c|c|}
\hline \multirow{3}{*}{ Treatments } & \multirow{3}{*}{$\begin{array}{c}\text { Rates } \\
\left(\mathrm{kg} \mathrm{a.i.}^{-1} \mathbf{h a}^{-1}\right)\end{array}$} & \multicolumn{6}{|c|}{ Injury $(\%)^{\dagger}$} \\
\hline & & \multicolumn{3}{|c|}{45 DAT } & \multicolumn{3}{|c|}{60 DAT } \\
\hline & & Grapefruit & Orange & Tangerine & Grapefruit & Orange & Tangerine \\
\hline Flazasulfuron & 0.05 & $9 \mathrm{a}^{\ddagger}$ & $0 \mathrm{c}$ & $0 \mathrm{c}$ & $11 \mathrm{a}$ & $0 \mathrm{~b}$ & $0 \mathrm{~b}$ \\
\hline Flazasulfuron + Glyphosate & $0.05+0.84$ & $5 \mathrm{~b}$ & $0 \mathrm{c}$ & $0 \mathrm{c}$ & $4 \mathrm{~b}$ & $0 \mathrm{~b}$ & $0 \mathrm{~b}$ \\
\hline Flazasulfuron + Glyphosate & $0.07+1.70$ & $11 \mathrm{a}$ & $0 \mathrm{c}$ & $0 \mathrm{c}$ & $15 \mathrm{a}$ & $0 \mathrm{~b}$ & $0 \mathrm{~b}$ \\
\hline Flazasulfuron + Diuron & $0.05+2.70$ & $9 \mathrm{a}$ & $0 \mathrm{c}$ & $0 \mathrm{c}$ & $13 \mathrm{a}$ & $0 \mathrm{~b}$ & $0 \mathrm{~b}$ \\
\hline Norflurazon + Diuron & $2.70+2.70$ & $3 \mathrm{bc}$ & $0 \mathrm{c}$ & $0 \mathrm{c}$ & $3 \mathrm{~b}$ & $0 \mathrm{~b}$ & $0 \mathrm{~b}$ \\
\hline
\end{tabular}

${ }^{\dagger}$ Visual injury was based on a $0 \%-100 \%$ rating scale where 0 is no injury and 100 is complete death of plants; ${ }^{\dagger}$ Means followed by the same letter within the rating period are not significantly different at $\alpha=5 \%$. 
increase in bermudagrass density with flazasulfuron application indicating tolerance to flazasulfuron [13]. Slight but acceptable injury $(<21 \%)$ to creeping bentgrass was observed when flazasulfuron was applied at rates ranging from 0.001 to $0.009 \mathrm{~kg}$ a.i. $\mathrm{ha}^{-1}$ at varying application frequencies [21]. Other crops such as grapes (2 year-old vines) tolerated flazasulfuron quite well with rates as high as $0.05 \mathrm{~kg} \cdot \mathrm{ha}^{-1}$ [22]. In sugarcane, slight toxicity symptoms were observed with the postemergence application of flazasulfuron at $0.10 \mathrm{~kg}$ a.i. ha ${ }^{-1}$ but there was no significant reduction in growth and stalk yield [23]. Pasture species, particularly perennial ryegrass (Lolium perenne L.), was injured with the application of flazasulfuron at the rate of 4 and $5 \mathrm{~g} \cdot \mathrm{ha}^{-1}$ [24].

Varying results on turf grass tolerance to flazasulfuron tank mixed with other herbicides have also been reported. Brecke et al. [25] reported that bermudagrass was not injured by flazasulfuron when tank mixed with pendimethalin, prodiamine, or quinchlorac. However, Wells et al. [26] reported that bermudagrass was injured when flazasulfuron was tank mixed with imazapic although the injury $(<30 \%)$ was within the acceptable limit.

Overall results of the citrus response studies indicated that flazasulfuron at $0.05 \mathrm{~kg}$ a.i. $\mathrm{ha}^{-1}$ was well tolerated. Application of flazasulfuron at 0.10 and $0.20 \mathrm{~kg}$ a.i. $\mathrm{ha}^{-1}$ may not be acceptable due to high injury to citrus, particularly on grapefruit. Our results have indicated that injury to grapefruit was $42 \%$ and $70 \%$ at 0.10 and 0.20 $\mathrm{kg}$ a.i. ha ${ }^{-1}$, respectively. Tank mixing flazasulfuron at $0.05 \mathrm{~kg}$ a.i. ha ${ }^{-1}$ with glyphosate at $0.84 \mathrm{~kg}$ a.i. $\mathrm{ha}^{-1}$ resulted in not more than 5\% injury to citrus. Increasing both rates of flazasulfuron and glyphosate increased injury to grapefruit to $19 \%$. No injury to sweet orange and tangerine was observed with any herbicides treatments evaluated.

\subsection{Weed Control}

Predominant grass species in the study sites were a mixture of Texas panicum (Urochloa texana (Buckl.) R. Webster), guinea grass (Urochloa maxima (Jacq.) R. Webster), and bermudagrass (Cynodon dactylon (L.) Pers.). Texas panicum was the primary grass species at the Frostproof site, while guinea grass was the primary grass species at the Dundee and Haines City site. Florida/ Brazil pusley, common ragweed (Ambrosia artemisiifolia L.), and Spanishneedles (Bidens bipinatta L.) were commonly found at all three sites, while horseweed (Conyza canadensis (L.) Cronq.) and eastern black nightshade (Solanum ptychanthum Dun.) were only found at the Dundee and Haines City sites.

Flazasulfuron alone did not provide adequate grass control in citrus. Overall grass control was similar across flazasulfuron rates and was $<25 \%$ (data not shown).
These results were contrary to those reported in turf. Previous studies have shown that flazasulfuron effectively controlled grass weeds such as tall fescue (Lolium arundinaceum (Schreb.) S.J. Darbyshire) [11], southern crabgrass (Digitaria ciliaris (Retz.) Koel [10], smooth crabgrass (Digitaria ischaemum (Schreb. ex Schweig) Schreb. ex Muhl.) [27], annual bluegrass (Poa апnиa L.), and perennial ryegrass $[11,15]$. Furthermore, Brecke et al. [25] reported that flazasulfuron $0.05 \mathrm{~kg}$ a.i. $\mathrm{ha}^{-1}$ provided similar or greater control of southern crabgrass 60 DAT than MSMA.

Control of broadleaf weeds with flazasulfuron varied by rates and rating times. (Figure 1). In general, initial weed control at 15 DAT was low, then increased until 45 DAT, then declined thereafter. Florida/Brazil pusley was moderately controlled with the application of high rates of flazasulfuron $\left(0.10\right.$ and $\left.0.20 \mathrm{~kg} \cdot \mathrm{ha}^{-1}\right)$ compared to the low rate; however, control at any flazasulfuron rate did not exceed $75 \%$ at 45 DAT. By 60 DAT, control was similar across flazasulfuron rates (Figure 1(A)). Initial control of Spanishneedles at 15 DAT varied by rate such that control with flazasulfuron at $0.20 \mathrm{~kg}$ a.i. $\mathrm{ha}^{-1}$ was higher than the lower rates $\left(0.05\right.$ and $0.10 \mathrm{~kg}$ a.i. $\left.\mathrm{ha}^{-1}\right)$. From 30 to 60 DAT, control of Spanishneedles (78\% $85 \%$ ) was similar across flazasulfuron rates at $30 \mathrm{DAT}$, but later in the season control was reduced $(60 \%)$ (Figure 1(B)). Horseweed control with flazasulfuron varied by rates at 15 DAT such that there was greater control $(73 \%)$ with flazasulfuron at $0.20 \mathrm{~kg}$ a.i. $\mathrm{ha}^{-1}$ compared to the lower rates (Figure 1(C)). At 30 to $60 \mathrm{DAT}$, control of horseweed was similar at all flazasulfuron rates. Common ragweed was not controlled by flazasulfuron at any rate. Highest control $(<70 \%)$ was at $30 \mathrm{DAT}$ and declined thereafter, and by 60 DAT control did not exceed 25\% (Figure 1(D)).

Results of these studies indicated broadleaf weed control with flazasulfuron alone varied among species. Other studies indicated that season-long control of wild violets (Viola spp.) and field pansy (Viola rafinesquei Greene) was achieved with a single application of flazasulfuron at rates much lower $\left(0.008\right.$ to $0.039 \mathrm{~kg}$ a.i. $\left.\mathrm{ha}^{-1}\right)$ than those used in this study [12]. Flazasulfuron at rates greater than $0.035 \mathrm{~kg}$ a.i. $\mathrm{ha}^{-1}$ controlled yellow rocket (Barbarea vulgaris R. Br.) and prostrate knotweed (Polygonum aviculare L.) $90 \%$ at 8 WAT [11]. Similarly, Virginia buttonweed was controlled with flazasulfuron at 0.05 and 0.08 $\mathrm{kg}$ a.i. ha ${ }^{-1}[14]$, as was other broadleaf weeds such as lawn burweed (Soliva sessilis Ruiz \& Pavon), henbit (Lamium amplexicaule L.), and Viola species [12,13]. However, some weed species, such as common lespedeza (Lespedeza striata (Thunb.) H.\&A.) and buckhorn plantain (Plantago lanceolata L.), were not effectively controlled with flazasulfuron $[11,28,29]$. In this study, common ragweed was not controlled by any of the flazasulfuron rates 

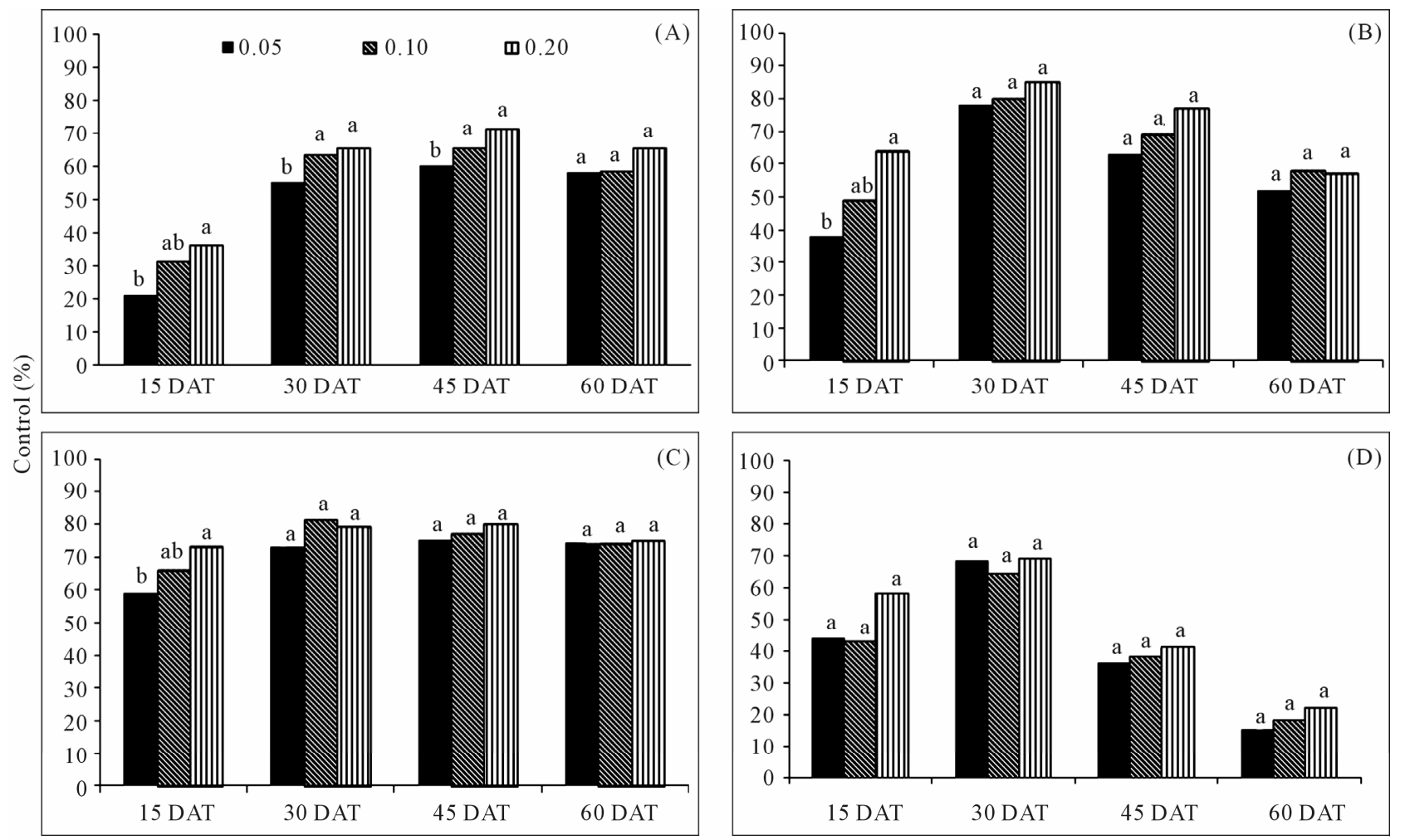

Days after treatment

Figure 1. Control of Florida/Brazil pusley (A), Spanishneedles (B), horseweed (C), and common ragweed (D) with different rates of flazasulfuron. Means within a rating period for each weed species followed by the same letter are not significantly different at $\alpha=\mathbf{0 . 0 5}$.

evaluated.

Overall grass control was better with tank mixes than flazasulfuron alone at all rating periods (Figure 2). Grass control at 15, 30, and 60 DAT was greater when flazasulfuron was tank mixed with glyphosate compared to other tank mix partners. However, overall grass control with flazasulfuron at $0.05 \mathrm{~kg} \cdot \mathrm{ha}^{-1}$ plus glyphosate 0.84 $\mathrm{kg} \cdot \mathrm{ha}^{-1}$, and flazasulfuron at $0.05 \mathrm{~kg}$ a.i. ha ${ }^{-1}$ plus diuron at $2.70 \mathrm{~kg}$ a.i. $\mathrm{ha}^{-1}$ was similar to norflurazon at $2.70 \mathrm{~kg}$ a.i. ha ${ }^{-1}$ plus diuron at $2.70 \mathrm{~kg}$ a.i. $\mathrm{ha}^{-1}$. The greatest control $(90 \%)$ of grasses was achieved at 45 DAT with the application of flazasulfuron at $0.07 \mathrm{~kg}$ a.i. $\mathrm{ha}^{-1}$ plus glyphosate at $1.70 \mathrm{~kg}$ a.i. $\mathrm{ha}^{-1}$ while the other tank mix treatments gave similar control. Similar results were reported by Brecke et al. [25] but using different herbicides as tank mix partners of flazasulfuron in turf. They reported that greater control of southern crabgrass was achieved when flazasulfuron was tank mixed with other herbicides such as prodiamine, pendimethalin, or quinchlorac in turf. Askew et al. [30] reported that flazasulfuron at 0.002 and $0.004 \mathrm{~g}$ a.i. ha ${ }^{-1}$ tank mixed with quinchlorac at $0.307 \mathrm{~kg}$ a.i. ha ${ }^{-1}$ gave $80 \%$ and $73 \%$ control of smooth crabgrass, respectively.

Tank mixing flazasulfuron with other herbicides improved broadleaf weed control (Figures 3 and 4). Except for eastern black nightshade and horseweed, broadleaf weed control at 15 DAT was significantly better with all tank mix treatments compared to flazasulfuron applied alone (Figures 3 and 4). By 60 DAT, control of all broadleaf weeds declined but was still acceptable (> $60 \%)$. Good control $(65 \%-74 \%$ and $71 \%-78 \%)$ of pusley species was achieved with flazasulfuron at 0.70 $\mathrm{kg}$ a.i. ha ${ }^{-1}$ plus glyphosate at $1.70 \mathrm{~kg}$ a.i. $\mathrm{ha}^{-1}$, and flazasulfuron plus diuron at 15 and 30 DAT. Control with flazasulfuron plus glyphosate (at lower rates for both herbicides) was comparable with flazasulfuron plus diuron and norflurazon plus diuron at all rating periods. By 60 DAT, control with all herbicide treatments decreased with flazasulfuron tank mixed with either glyphosate or diuron, giving similar level of control. Overall, there was good control $(>60 \%)$ of Florida/Brazil pusley with all tank mix treatments.

There was excellent control of Spanishneedles $(>85 \%)$ with all tank mix treatments at 15 DAT (Figure 3(B)). At 30 and 45 DAT, all treatments containing flazasulfuron gave $91 \%$ to $94 \%$ and $88 \%$ to $93 \%$ control, respectively; however, control with flazasulfuron tank mixed with diuron was similar to flazasulfuron alone and norflurazon plus diuron at 30 DAT. Control for Spanishneedles declined with time, and it was $70 \%-81 \%$ by 60 DAT. 


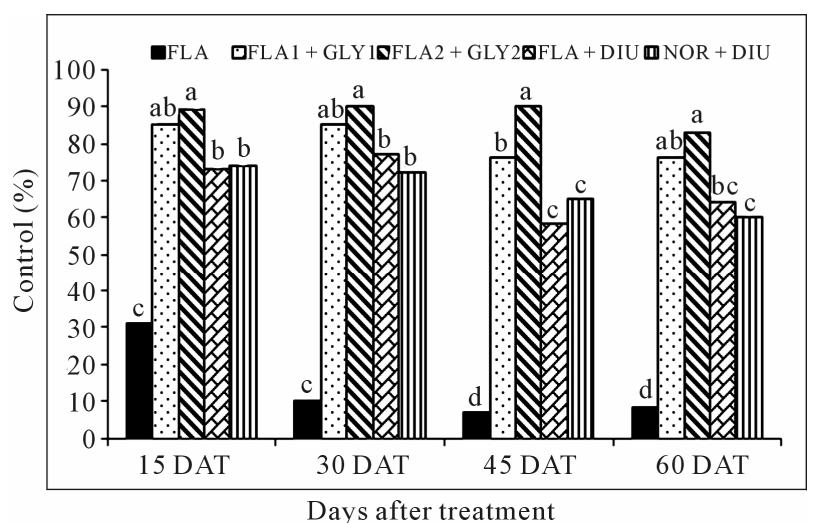

Figure 2. Overall grass control with the different herbicide treatments. FLA is flazasulfuron at $0.05 \mathrm{~kg}$ a.i. $\mathrm{ha}^{-1}$, FLA1 + GLY1 is flazasulfuron at $0.05 \mathrm{~kg}$ a.i. $\mathrm{ha}^{-1}$ plus glyphosate at $0.84 \mathrm{~kg}$ a.i. $\mathrm{ha}^{-1}$, FLA2 + GLY2 is flazasulfuron at $0.07 \mathrm{~kg}$ a.i. ha ${ }^{-1}$ plus glyphosate at $1.70 \mathrm{~kg}$ a.i. $\mathrm{ha}^{-1}, \mathrm{FLA}+$ DIU is flazasulfuron at $0.05 \mathrm{~kg}$ a.i. $\mathrm{ha}^{-1}$ and diuron at $2.70 \mathrm{~kg}$ a.i. $\mathrm{ha}^{-1}$, and NOR + DIU is norflurazon at $2.70 \mathrm{~kg}$ a.i. ha ${ }^{-1}$ plus diuron at $2.70 \mathrm{~kg}$ a.i. ha ${ }^{-1}$. Means within a rating period are not significantly different at $\alpha=0.05$.

Control of common ragweed was higher with all tank mix treatments compared to flazasulfuron alone at all rating periods except at 45 DAT (Figure 3(C)).

Eastern black nightshade control did not vary among herbicide treatments at 15 DAT (Figure 4(A)). At 30 DAT, control with flazasulfuron tank mixed with either glyphosate or diuron was higher compared to flazasulfuron alone and the growers standard. The highest control of eastern black nightshade (93\%) was achieved at 45 DAT with flazasulfuron at $0.07 \mathrm{~kg}$ a.i. $\mathrm{ha}^{-1}$ plus glyphosate at $1.70 \mathrm{~kg}$ a.i. ha ${ }^{-1}$. Additionally, control of eastern black nightshade with flazasulfuron tank mixed with glyphosate at $0.84 \mathrm{~kg}$ a.i. $\mathrm{ha}^{-1}$ or diuron and norflurazon plus diuron were similar and significantly higher than flazasulfuron alone. By $60 \mathrm{DAT}$, control of eastern black nightshade with all herbicide tank mixtures declined but was still acceptable with control ranging from $65 \%$ to $83 \%$. Early horseweed control at 15 DAT was similar across herbicide treatments (Figure 4(B)). By 30 DAT, all tank mix treatments provided better control of horseweed compared to flazasulfuron alone. From 30 to 60 DAT, all herbicide treatments containing flazasulfuron provided similar control of horseweed. However, control of horseweed with flazasulfuron at $0.05 \mathrm{~kg}$ a.i. $\mathrm{ha}^{-1}$ tank mixed with glyphosate at $0.84 \mathrm{~kg}$ a.i. $\mathrm{ha}^{-1}$ or diuron was comparable to flazasulfuron alone and norflurazon plus diuron at 45 and 60 DAT. Overall, there was good control of horseweed with all herbicide treatments which averaged $70 \%$ across rating periods.

\section{Conclusions}

The results of this study indicated a differential response
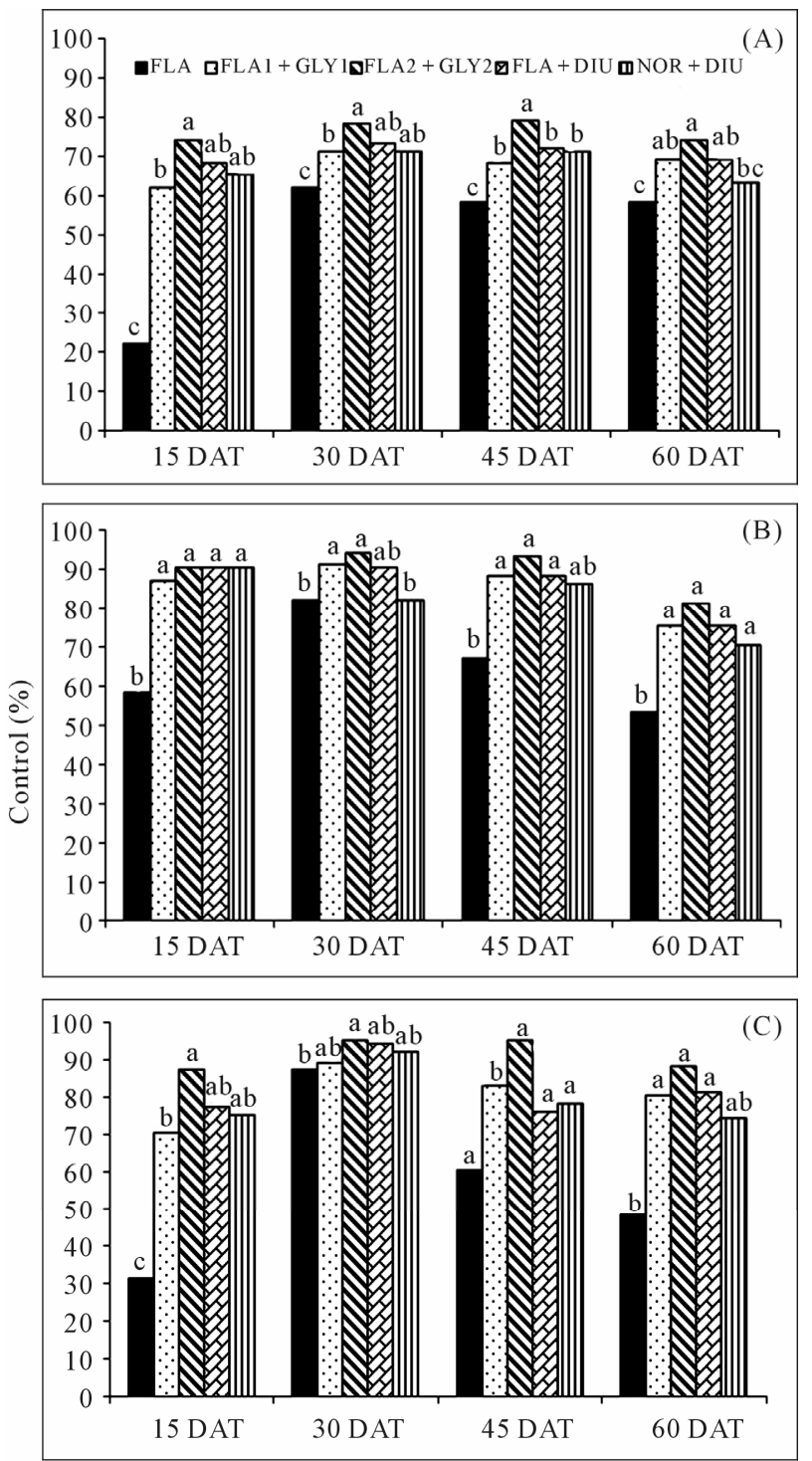

Days after treatment

Figure 3. Control of FL/BR pusley (A), Spanishneedles (B) and common ragweed $(C)$ using different herbicide treatments. FLA is flazasulfuron at $0.05 \mathrm{~kg}^{\text {a.i. }} \mathrm{ha}^{-1}$, FLA1 + GLY1 is flazasulfuron at $0.05 \mathrm{~kg}$ a.i. $\mathrm{ha}^{-1}$ plus glyphosate at $1.70 \mathrm{~kg}$ a.i. $\mathrm{ha}^{-1}$, FLA2 + GLY2 is flazasulfuron at $0.07 \mathrm{~kg}$ a.i. $\mathrm{ha}^{-1}$ plus glyphosate at $1.70 \mathrm{~kg}$ a.i. $\mathrm{ha}^{-1}$, FLA + DIU is flazasulfuron at $0.05 \mathrm{~kg}$ a.i. $\mathrm{ha}^{-1}$ plus diuron at $2.70 \mathrm{kga.i}$. $\mathrm{ha}^{-1}$, and NOR + DIU is norflurazon at $2.70 \mathrm{~kg}$ a.i. ha ${ }^{-1}$ plus diuron at $2.70 \mathrm{~kg}$ a.i. ha ${ }^{-1}$. Means within a rating period followed by the same letters are not significantly different at $\alpha=0.05$.

among citrus species to flazasulfuron, with grapefruit being the most sensitive and tangerine the least sensitive. Phytotoxicity was observed when flazasulfuron was applied alone or when tank mixed with glyphosate or diuron; however, injury to citrus was reduced when flazasulfuron was tank mixed with either glyphosate or diuron. Further studies are needed to understand the factors 


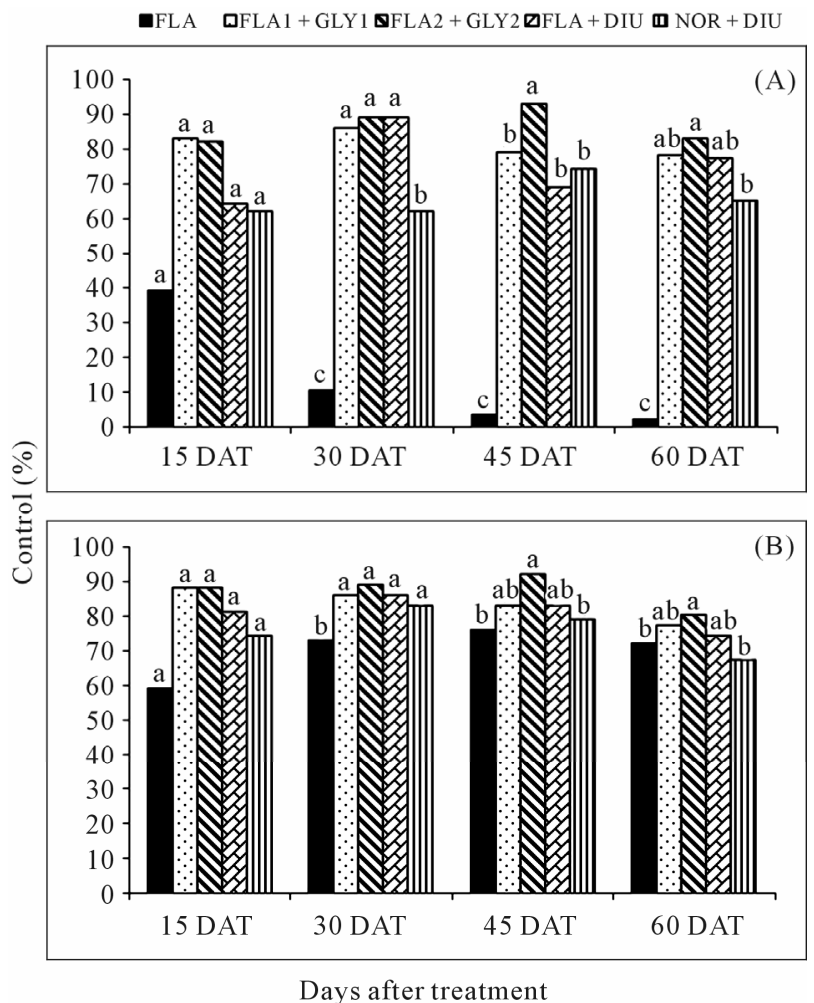

Figure 4. Control of eastern black nightshade (A) and horseweed (B) using different herbicide treatments. FLA is flazasulfuron at $0.05 \mathrm{~kg}$ a.i. ha, FLA1 + GLY1 is flazasulfuron at $0.05 \mathrm{~kg}_{\text {a.i. }} \mathrm{ha}^{-1}$ plus glyphosate at $0.84 \mathrm{~kg}^{\text {a.i. }} \mathrm{ha}^{-1}$, FLA2 + GLY2 is flazasulfuron at $0.07 \mathrm{~kg}^{\text {a.i. }} \mathrm{ha}^{-1}$ plus glyphosate at $1.70 \mathrm{~kg}$ a.i. $\mathrm{ha}^{-1}$, FLA + DIU is flazasulfuron at $0.05 \mathrm{~kg}$ a.i. $\mathrm{ha}^{-1}$ plus diuron at $2.70 \mathrm{~kg}$ a.i. $\mathrm{ha}^{-1}$, and NOR + DIU is norflurazon at $2.70 \mathrm{~kg}$ a.i. $\mathrm{ha}^{-1}$ plus diuron at $2.70 \mathrm{~kg}$ a.i. $\mathrm{ha}^{-1}$. Means within a rating period followed by the same letters are not significantly different at $\alpha=0.05$.

that may impact phytotoxicity of flazasulfuron on grapefruit trees.

Flazasulfuron alone at the rates tested did not provide adequate control of grasses and some broadleaves weeds. Tank mixing flazasulfuron with glyphosate or diuron improved efficacy on weeds. However, the rate which adequately controlled weeds proved to be detrimental to young grapefruit trees. The rate at which sufficient control of weeds is attained and the rate at which there is minimal phytotoxicity should be determined before flazasulfuron can be commercially used in citrus. Furthermore, studies on the efficacy of flazasulfuron and other tank mixture combinations with other postemergence herbicides should also be explored.

\section{REFERENCES}

[1] National Agricultural Statistics Service (NASS), "Florida Citrus Statistics 2009-2010," 2011.

http:/www.nass.usda.gov/statistics_bystate/Florida/publi cations/citrus/fcs/2009-10/fcs0910.pdf

[2] T. M. Spann, R. A. Atwood and J. Yates, "Dooryard Citrus Production: The Value of the Florida Citrus Industry to Florida Residents," 2008, Horticultural Sciences Department, Florida Cooperative Extension Service, UF/ IFAS, Gainesville, 2011.

http://www.edis.ifas.ufl.edu/hs381

[3] M. Singh and S. D. Sharma, "Benefits of Triazine Herbicides and Other Weed Control Technology in Citrus Management," In: H. M. Lebaron, J. E. McFarland and O. C. Burnside, Eds., The Triazine Herbicides-50 Years Revolutionizing Agriculture, Elsevier, San Diego, 2008, pp. 199-209.

[4] S. H. Futch and M. Singh, "2011 Florida Citrus Pest Management Guide: Weeds," In: M. E. Rogers, M. M. Dewdney and T. M. Spann, Eds., 2011 Florida Citrus Pest Management Guide, University of Florida, IFAS, Gainesville, 2011, pp. 139-151.

[5] S. D. Sharma and M. Singh, "Effect of Timing and Rates of Application of Glyphosate and Carfentrazone Herbicides and Their Mixtures on the Control of Some Broadleaf Weeds," HortScience, Vol. 42, No. 5, 2007, pp. 1221-1226.

[6] I. Heap, "International Survey of Herbicide Resistant Weeds," 2011. http://www.weedscience.org

[7] R. S. Chandran and M. Singh, "Survey and Control of Brazil Pusley (Richardia brasiliensis) in Florida Citrus," Proceedings of the Florida State Horticultural Society, Vol. 116, 2003, pp. 211-214.

[8] M. D. Grove, "An Update on the Pending New Registrations of Flazasulfuron in the United States," Proceedings of the Weed Science Society of America, Vol. 64, 2011, p. 196.

[9] Anonymous, "Flazasulfuron Wide Spectrum Herbicide," 2011.

http://www.iskweb.co.jp/products/pdf/flazasulfuron.pdf

[10] B. J. Brecke and J. B. Unruh, "Weed Management in Warm Season Turfgrass with CGA 362622," Proceedings of the Southern Weed Science Society, Vol. 55, 2002, p. 52.

[11] J. B. Beam, W. L. Baker and S. D. Askew, "Efficacy of Flazasulfuron for Weed Control in Bermudagrass," Proceedings of the Southern Weed Science Society, Vol. 57, 2004, p. 121.

[12] L. S. Warren and F. H. Yelverton, "Viola Species Control Using Sulfonylurea Herbicides," Proceedings of the Southern Weed Science Society, Vol. 57, 2004, p. 94.

[13] M. J. Taylor, J. D. Byrd, K. C. Hutto and D. W. Wells, "Winter Weed Control with ALS-Inhibiting Herbicides in Bermudagrass Turfgrass," Proceedings of the Southern Weed Science Society, Vol. 58, 2005, p. 106.

[14] K. C. Hutto, B. J. Brecke and J. B. Unruh, "Comparison of Flazasulfuron to Pyridine Herbicides for Virginia Buttonweed (Diodia virginiana) Control," Weed Technology, Vol. 22, No. 2, 2008, pp. 351-353. doi:10.1614/WT-07-062.1

[15] J. T. Brosnan, A. W. Thomas, P. E. McCullough, G. R. Armel, G. J. Breeden, J. C. Sorochan and T. C. Mueller, 
"Efficacy of Flazasulfuron for Control of Annual Bluegrass (Poa annua) and Perennial Ryegrass (Lolium perenne) as Influenced by Nitrogen," Weed Science, Vol. 58, No. 4, 2010, pp. 449-456. doi:10.1614/WS-D-09-00019.1

[16] D. W. Wells, J. M. Taylor, J. D. Byrd, Jr. and K. C. Hutto, "Virginia Buttonweed Control with ALS-Inhibiting Herbicides Applied Alone and with Trimec Classic," Proceedings of the Southern Weed Science Society, Vol. 57, 2004, p. 106.

[17] K. C. Hutto, B. J. Brecke and J. B. Unruh, "Flazasulfuron for Chamberbitter Control in Turfgrass," Proceedings of the Southern Weed Science Society, Vol. 59, 2006, p. 105.

[18] F. H. Yelverton, T. W. Gannon, J. D. Hinton and L. S. Warren, "Weed Control and Turfgrass Tolerance to Flazasulfuron," Proceedings of the Southern Weed Science Society, Vol. 56, 2003, p. 101.

[19] B. J. Brecke, B. Unruh and D. P Telenko, "Flazasulfuron for Weed Management in Warm-Season Turfgrass," Proceedings of the Southern Weed Science Society, Vol. 62, 2009, p. 398.

[20] J. B, Willis, D. B. Ricker and S. D. Askew, "Sulfonylurea Herbicides Applied During Early Establishment of Seeded Bermudagrass," Weed Technology, Vol. 21, No. 4, 2007, pp. 1035-1038. doi:10.1614/WT-07-058.1

[21] M. J. Goddard, S. D. Askew, J. B. Willis and M. B. Grove, "Flazasulfuron: A Potential Solution for Selective Perennial Ryegrass Control in Creeping Bentgrass," Proceedings of the Northeast Weed Science Society, Vol. 61, 2007, p. 25.

[22] A. F. Senasac and I. Tsonakis-Bradley, "Weed Management Research in Ornamentals, Turfgrass, Vegetables and Fruits," 2009 Research Summary, Cornell University Cooperative Extension of Suffolk County, Riverhead, New York, 2011.

http://www.ccesuffolk.org/assets/weed-science/document s/weed-mgmt-res-cucesc-2009.pdf
[23] E. B. Durigan-Marcel, J. C. Durgan and M. Gustavo, "Selectivity of the Herbicide Flazasulfuron Applied after Postemergence in Sugarcane (Saccharum spp. L.) Crop," Journal of Environmental Science and Health, Vol. 40, No. 1, 2005, pp. 177-180.

[24] T. K. James, A. Rahman and P. De Jong, "Flazasulfuron for Control of Ragwort (Senecio jacobeae) in Pasture," Proceedings of the 50th New Zealand Plant Protection Conference, 1997, pp. 477-481. http://www.nzpps.org/journal/50/nzpp_504770.pdf

[25] B. J. Brecke, K. C. Hutto and J. B. Unruh, "Postemergence Southern Crabgrass (Digitaria cilliaris) Control with Sulfonylurea Herbicides," Weed Technology, Vol. 22, No. 2, 2008, pp. 354-358. doi:10.1614/WT-07-063.1

[26] D. W. Wells, R. H. Walker and J. L. Belcher, "Effects of Imazapic and Flazasulfuron on Dallisgrass in Bermudagrass Turf," Proceedings of the Southern Weed Science Society, Vol. 62, 2009, p. 88.

[27] J. B, Willis, D. B. Ricker and S. D. Askew, "Riviera Bermudagrass Response to Pre-Seeding Applications of Sulfonylurea Herbicides," Applied Turfgrass Science, 2011. http://www.plantmanagementnetwork.org/pub/ats/researc $\mathrm{h} / 2008 /$ riviera

[28] F. H. Yelverton and L. S. Warren, "Postemergence Common Lespedeza Control Using Flazasulfuron Combinations," 2007 Turfgrass Research Report: Weed Control and PGR's, Crop Science Department, North Carolina State University, Raleigh.

[29] J. Boyd, "Common Lespedeza Control in Cavalier Zoysiagrass," Arkansas Turfgrass Report 2008, Arkansas Agricultural Experiment Station Research Service, Vol. 568, 2009, pp. 9-11.

[30] S. D. Askew, M. J. Goddard and J. B. Willis, "Herbicide Combinations with Flazasulfuron for Broad Spectrum Weed Control in Creeping Bentgrass," Proceedings of the Southern Weed Science Society, Vol. 62, 2009, p. 397. 